\title{
Chapter 4 \\ Teacher Education Policies in China Since the Mid-1990s
}

\author{
Congman Rao
}

Since the mid-1990s, teacher education in China has entered a new period of transformation, mirroring larger rapid societal development. Although quality improvement has been the theme of teacher education development in China since the mid-1990s, this period of more than 20 years can still be divided into three periods: the phase of system restructuring (from the mid-1990s to 2005), the phase of capacity building (from 2005 to 2016), and the phase of revitalization (since 2017). This chapter reviews the changes to the background, goals, content, and impacts in teacher education policies since the 1990s and then discusses its future development.

\subsection{System Restructuring}

\subsubsection{Policy Background}

\subsubsection{The Full Range of Social Transformation}

Social transformation during the period from the mid-1990s to 2005 shaped teacher education reform and development in China. There are three kinds of social transformation impacting teacher education in their own way.

C. Rao $(\bowtie)$

Northeast Normal University, Changchun, China

e-mail: raocm506@nenu.edu.cn 
Transformation from a Planned Economy to a Market Economy

In the early 1990s, the Communist Party of China (CPC) proposed that the establishment of a socialist market economy should be the goal and direction for China's economic system reform. With the transformation of the economic system, the closed teacher education system that was suitable for the old, planned economic system increasingly showed its inadaptability. Social transformation accelerated the collapse of the old teacher education system; it also provided the impetus for the initiation and development of a new teacher education system.

Transformation from an Agricultural Society to an Industrial and Information Society

China has been experiencing a transformation from an agricultural society to an industrial society on the one hand, as well as the transformation from an industrial society to an information society at the same time. To meet the demands of an information, knowledge, and network-based society, the 16th National Congress of CPC in 2002 clearly set a target to construct a learning society, which brought up new requirements for teachers and teacher education. Standards of teacher quality and teacher education that were set in the early 1990s were clearly unable to meet this demand.

Transformation from a Rural and Poor Society to an Urban and Affluent Society

After the Reform and Opening-up of China, rapid economic growth resulted in an abrupt rise in the income and living standard of residents. The increase in national income and improvement in living standard meant, for example, that citizens could budget more for their children's education and that their demand for education would also increase. In addition, people's expectations of the quality of education became higher, and they became more demanding about schools and teachers. Given the crucial role of teachers in improving quality of education, reforming teacher education and improving teacher quality became a top priority of the education reform.

\subsubsection{Quality-Oriented Basic Education Reform}

China proposed and started to implement quality-oriented education in 1990s. To fully implement quality-oriented education, China began comprehensive, in-depth, and enduring curriculum reform. In June of 1999, the CPC Central Committee and the State Council of China issued Decisions on Deepening Educational Reform and 
Promoting Quality-Oriented Education in an All-Round Way, which clearly defined the guidelines and fundamental strategies for the comprehensive promotion of quality-oriented education in China. This policy set the direction for constructing the Chinese education system in the twenty-first century (CPCCC and SC 1999). In 2001, the promulgation of the Outline for Basic Education Curriculum Reform by the Ministry of Education (MOE) started a new round of basic education curriculum reform in China (DTEMOE 2009: 219-223).

The basic education reform that moved from examination-oriented to qualityoriented education called for role-changing of school teachers to be designers of a student-friendly learning environment, organizers and facilitators, reflective and collaborative researchers, curriculum developers, and classroom managers, as well as disseminators of knowledge, guides, supervisors, and evaluators. Accordingly, teacher education needed to be changed to meet the new requirements, too. Thus, teacher education reform was focused on how to establish a new teacher education system that would be compatible with the transformation of quality-oriented education.

\subsubsection{Moving Toward a Balanced Relationship Between Supply and Demand of School Teachers}

China long suffered from a teacher shortage from 1949 to the 1990s. However, since the late 1990s, the relationship between the supply and demand of teachers has changed, mainly due to factors such as the national birth-control policy, expansion of higher education, and improvement of teachers' economic and social status. As a result, the teacher shortage was eased since the beginning of the twenty-first century, and the number of teachers in primary and junior high schools decreased gradually (Rao 2007).

\subsubsection{Objective, Content, and Effect of the Policies}

As a result of growing educational needs, the teacher education policies in China during the period from the mid-1990s to 2005 introduced teaching professionalization as a guiding concept, aimed to improve teacher quality and restructure the teacher education system.

\subsubsection{Structural Reform of the Preservice Teacher Preparation System}

The structural reform of teacher preparation included horizontal restructuring to open up teacher preparation system and vertical restructuring to upgrade all teacher preparation to college level (Rao 2007). 


\section{Opening-Up of Teacher Preparation System: Horizontal Restructuring}

In China, teacher preparation from 1950 to the early 1990s was confined in a closed and exclusive system, in which specialized normal schools, colleges, and universities were the only legitimate institutions to prepare teachers. The mission of those institutions at that time was exclusively focused on teacher preparation. However, since the 1990s, many normal colleges and universities began to set up non-teacher education specialties or programs, striving to become comprehensive higher education institutions. According to incomplete statistics on the specialties in normal colleges and universities, by the end of 1990s, non-teacher education programs made up 50\% of all specialties in most national normal universities (Rao 2013: 275). In addition to this establishment of non-teacher education programs, the wave of amalgamation of higher education institutions (HEIs) since the early 1990s has also had a major impact on the existing normal education system. From 1990 to July of 2005, a total of 115 higher normal colleges were merged with other HEIs or renamed as comprehensive colleges and universities. By July of 2005, the number of normal colleges and universities decreased from 290 to 153 (Yu 2010: 94-97).

The goal of Chinese teacher education reform policies since the 1990s was set to build a diversified and open teacher education system. The Teachers Laws of the Peoples' Republic of China, issued in 1993, specified graduates from non-normal colleges and universities are eligible to teach in primary and secondary schools or vocational schools. This broke the traditional monopoly of the normal universities and started a diversified and open teacher education system.

In 2001, Decisions on Reform and Development of Basic Education by the State Council (2001) and the 10th 5-year Plan for the Construction of the Teaching Force of Primary and Secondary Schools by the MOE (2001) were launched and proposed further improvements to the opening-up of teacher education system to include comprehensive universities and normal colleges and universities as providers of teacher education. These abovementioned policies and regulations established the direction toward diversification and openness of teacher education system at the national policy level (DTEMOE Ed. 2009). According to the Department of Teacher Education of the MOE, by 2005, the number of non-normal colleges and universities providing teacher education at the undergraduate level reached 324, with graduates of teacher education accounting for $40 \%$ of all graduates of teacher education (DTEMOE 2006). Non-normal colleges and universities had become an important provider in Chinese teacher education.

\section{Upgrading All Teacher Education to the Higher Education Level: Vertical Restructuring}

In China, preservice teacher preparation was undertaken in three-level institutions with differentiated missions after 1949. Four-year normal universities and colleges prepare teachers working in senior high schools and vocational schools, graduates from 2- to 3-year junior normal colleges work in junior high schools, and secondary 
normal schools prepare teachers in primary schools and kindergartens. Since the end of the twentieth century, along with the implementation of the policies and measures to upgrade teachers' degrees, the teacher preparation system itself moved gradually into a process of upgrading. Decisions on Reform and Development of Basic Education stated clearly that "teacher education restructuring should be upgraded to realize the transition gradually from [a] three-level teacher preparation system to [a] two-level teacher preparation system" (DTEMOE. Ed 2009). The 10th 5-year Plan for Construction of the Teaching Force of Primary and Secondary Schools of 2001 asserted that "the restructuring of the layouts, levels, and types of normal schools, colleges, and universities should be upgraded to actualize the reasonable integration of normal schools, colleges, and universities ... making the level of teacher education institutions transit timely from 'three levels' to 'two levels"' (ibid., pp. 251-257). The National Working Conference on Teacher Education held in 2002 clearly advocated that the three-level teacher education system, consisting of junior college, undergraduate, and graduate levels (referred to as "a new three-level"), should be enacted gradually to fully upgrade school teachers' educational credentials.

The reform to upgrade all teacher education to the higher education level made some progress. According to the national education statistics, China's 4-year normal colleges and universities increased from 87 to 96 from 1999 to 2005; junior normal colleges decreased from 140 to 58 (including 17 newly built ones), and secondary normal schools decreased from 815 to 228 (MOE 2010).

The upgrading of all teacher education to the higher education level laid a foundation for the quality improvement of teacher education. However, merely upgrading teacher education to that level was not enough to ensure the improvement of teacher education quality. When this upgrade took place, carrying out corresponding design reform that is based on the requirements of professional education has proven indispensable. It is therefore worth exploring the extent of the notion of professional education was integrated organically into the process of upgrading teacher education in China during this phase.

\subsubsection{Construction of a Lifelong Learning System for Teachers}

Teachers are expected to be lifelong learners and to lead a lifelong learning (Guan 2004). Based on such an understanding, it was regarded as an important goal for teacher education reform and development in China to construct a lifelong learning system for teachers. The concept of lifelong education focuses on the reorganization and restructuring of the entire education system based on vertical and horizontal integration; these are essential to the reorganization of the teacher education system in China.

\section{Continuum: Vertical Integration}

Vertical integration refers to establishing a coherent and integrated lifelong teacher education institution, which replaces the separated but functionally undifferentiated preservice, induction, and in-service education institutions. The preservice and in- 
service teacher education systems in China were historically separated into two independent fields. Preservice teacher education was implemented in general normal education institutions, while in-service education was mainly undertaken in adult education institutions such as teacher training schools and institutes of education. These two kinds of institutions carried out their own duties separately. In the 1990s, the shortcomings and deficiencies of the separated system emerged in the following aspects. First, there were no communication or interchange between preservice and in-service education institutions, resulting in the issue of discontinued and unpractical teaching content. Second, in-service training institutions failed to deliver satisfactory training when compared with preservice training institutions. Third, there was a waste of educational resources due to duplicated allocation between preservice and in-service education institutions (Zhao 2000).

To solve these problems, as early as 1993, Shanghai began to integrate teacher education when the Shanghai Institute of Education and Shanghai Second Institute of Education were merged into East China Normal University to form the College of Continuing Education. Such reform of integrating teacher education institutions received support from the MOE and spread nationwide, particularly in the beginning of the twenty-first century. Normal universities and colleges designated professional colleges or departments for in-service training of school teachers. There were 265 provincial and district institutes of education in 1990. With the merger of HEIs, most of these were merged into normal education institutions and other HEIs, with only 64 provincial and district institutes remaining in 2005 (MOE 2010).

The reform of teacher education integration in China during this phase was in rapid development and yielded a good effect on institutional integration. However, this was not the ultimate goal because the highest priority has been the functional integration of preservice and in-service teacher education. To ensure the effective integration of teacher education, it is necessary to establish a role differentiation structure informed by lifelong learning theory that scopes what should be done and what can be achieved during the preservice and in-service phases (Zhang and Rao 2002). The goal of substantial integration of teacher education cannot be achieved without a clear structure of role differentiation among various teacher education institutions. On the contrary, the in-service training of teachers runs the risk of being belittled in general HEIs, especially in research universities.

\section{Networking: Horizontal Integration}

Horizontal integration refers to utilizing Internet to establish a lifelong learning system for teacher development by connecting the existing various opportunities and resources and overcoming geographical constraints. At the turn of the twenty-first century, based on information technology, a designated national teacher education network was built to provide distance teacher education. One salient example of such integration is the Program of the National Union of Teacher Education Networks launched by the MOE in 2003. This system integrated preser- 
vice and in-service education as well as the systems of teacher education institutions, satellite television, radio networks, and the Internet. It enabled selected high-quality teacher education resources to be co-constructed and widely shared across the country (DTEMOE Ed. 2009: 612-616). The networking of teacher education created favorable conditions for building a lifelong learning system where teachers can learn anytime, anywhere. However, the mechanisms for role differentiation and institutional collaboration among the main bodies in the network have not been fully established.

\subsection{Capacity Building}

\subsubsection{Policy Background}

\subsubsection{The National Strategy for Constructing an Innovative Country and Building a Harmonious Society}

Not long after entering the new century, China took independent innovation and the construction of an innovative country as one of the major strategic decisions to build a prosperous society in all respects. The National Conference of Science and Technology, held in 2006, issued the Guidelines of the National Program for the Medium- and Long-Term Scientific and Technological Development (2006-2020) (State Council 2010), which proposed a developmental strategy of independent innovation and the construction of an innovative country. To build an innovative country of a large pool of innovative talents, teacher quality matters. Therefore, how to cultivate high-quality teachers to meet the needs of building an innovative country became a prioritized issue in teacher education.

Almost at the same time, the Fourth Plenary Session of the 16th CPC Central Committee set forth a historic task of building a harmonious socialist society for the first time in 2004. In 2006, the Sixth Plenary Session of the 16th CPC Central Committee issued the Decisions on Major Issues on Building the Harmonious Socialist Society. In such a new context, the previously held and tested principle of "giving priority to efficiency with due consideration to equity," was challenged and gave way to equity principle. It was widely believed since then that social equity and justice featured a harmonious society and should become a core value for public policy.

\section{Dual Tasks of Improving Education Quality and Promoting Educational Equity}

Entering the new century, it has become a major contradiction in the field of Chinese education that limited high-quality educational resources cannot satisfy the increasing demands of the public for the high-quality education. China is facing two important practical problems in education development: first, how to con- 
tinuously improve education quality while moderately enlarging its scale and, second, how to allocate limited high-quality educational resources scientifically and rationally during the long-term process of education quality improvement. Consequently, two important tasks for the development of Chinese education were set to improve education quality and promote educational equity (Zhong 2010). The Guidelines of the National Program for Medium- and Long-Term Educational Reform and Development (2010-2020) (hereinafter referred to as Program Guidelines), issued in 2010, proposed to favorably allocate public resources to the poor and rural regions so as to narrow the gap between rural and urban education. Thus, the teacher education policy was reoriented and prioritized toward ensuring sufficient and quality teachers in the underdeveloped areas during this phase.

\section{Structural Surplus of School Teachers and Moving Toward Enhanced Professionality}

The relationship between supply and demand of school teachers has significantly influenced the reform and development of teacher education. After 2005, teacher oversupply appeared. For example, in 2008, there were 765,000 teacher education program graduates (including 303,000 undergraduates, 243,000 junior college graduates, and 219,000 secondary normal school graduates) and 171,000 graduates from non-teacher education programs who got teacher certificates through the teacher certification examination. This adds up to a total of 936,000 teacher candidates. However, new teachers recruited that year were 250,000, accounting for only $26.7 \%$ of the total graduates (Zhong 2010).

Paradoxically, such oversupply implies a structural shortage of certain subject teachers and high-quality teachers. The structural shortage of school teachers is mainly reflected in three areas: a shortage of high school teachers in the context of the rapid development of high school education; a shortage of teachers of some subjects, such as foreign language, music, physical education, and art; and a shortage of teachers in the west, rural, and minority areas due to unbalanced economic development. The sharp quality contradiction indicates that teachers' overall quality and professionality have failed to meet the needs of educational development and that there is an urgent need of improvement (Zhong 2010).

\subsubsection{Objectives, Contents, and Effects of the Policies}

Since about 2005, due to the aforementioned background, China's teacher education policy shifted its focus from system restructuring to capacity building, aiming at the quality improvement of teacher education and education equity. The capacity building was guided by teaching professionalization, including optimization of teacher resource allocation and rural teacher enhancement. 
Setting Standards: Construction of a Quality Assurance System for Teacher Education

Standards are the foundation of quality management and the basis for quality control as well. In 2004, the MOE began to develop standards of teacher education and promulgated Teacher Education Curriculum Standards (trial) in 2011 (MOE 2011), which shapes teacher education institutions in curriculum design, teaching materials development, delivery, and evaluation. Accreditation Standards for Teacher Education Programs (trial) were promulgated in 2014, which guides accreditation and quality evaluation of teacher education programs.

\section{Improving Practice: Promoting Practice-Oriented Teacher Education}

The integration of theory and practice is essential to teacher education as professional education. However, during the reform process since the 1990s, teaching practice of student teachers has been undermined by decreasing interests of schools to accept student teachers for their teaching practice, financial shortage for teaching practice, and insufficient opportunities for student teaching practice. Moreover, sufficient guidance and mentoring for student teachers in the field was lacking at that time (Zhou 1997; Ren et al. 1998).

In 2007, the MOE issued Opinions on Vigorously Promoting Student Teachers' Teaching Practice by Volunteer Teaching, which for the first time put forward in a policy that "normal universities and colleges should organize the seniors of teacher education programs to practice teaching in primary and secondary schools for no less than one semester according to local circumstances" and suggested "volunteer teaching" as "an important mechanism to promote the reform of teaching practice in teacher education" (MOE 2007). However, in the implementation, although the teaching practice opportunities for student teachers have been guaranteed through "volunteer teaching," the quality of guidance for the students' teaching practice cannot be guaranteed in most cases, which strongly affects the quality of teaching practice.

Opinions on Strengthening the Construction of the Teaching Force, issued by the State Council in 2012, and Opinions on Implementing Excellent Teacher Preparation Programs, issued by the Ministry of Education in 2014, reemphasized teaching practice of no less than one semester and proposed "to establish teacher education partnership between HEIs, local governments, and schools" and "Dual Mentoring System" in teaching practice.

As MOE stated in the Teacher Education Curriculum Standards (trial), "practiceoriented" was one of the three basic ideas of teacher education curriculum standards. What the policies intended to strengthen was not only teaching practice but also practice-oriented teacher education reform. Unfortunately, as MOE stated in Opinions on Strengthening Teaching Practice of Teacher Students in 2016, although the Ministry of Education continued to require HEIs to strengthen teaching practice and to implement practice-oriented teacher preparation, its effectiveness has not yet 
been fully demonstrated, with teaching practice still being a weak link in teacher preparation (MOE 2016). To further promote practice-oriented teacher education, MOE issued Opinions on Strengthening Teaching Practice of Teacher Students, drawing a comprehensive design for the teaching practice of teacher students from aspects of objective, content, form, guidance, assessment, base, fund, etc.

\subsubsection{Degree Upgrade: Expanding Graduate-Level Teacher Education}

It is an international trend to vigorously develop postgraduate-level teacher education (Sato 2015: 10; Nasukawa and Watanabe 2014: 57-146; Xu 2008). After upgrading all teacher education to the higher education level, China began to increasingly develop postgraduate teacher education. As early as in 1996, China commenced its pilot reform in postgraduate teacher education under the framework of professional degree education (i.e., the Master of Education degree). The MOE issued Opinions on How to Carry out the Work of Cultivating Full-Time Professional Degree Postgraduate Students on March 19, 2009, and decided then to expand the scale of recruitment of new graduates as full-time professional degree students (MOE 2009). According to this document, the Master of Education programs (hereinafter referred to as "MEd. programs") began to shift from recruiting only inservice school teachers and educational administrators to recruiting both new graduates and in-service educational staff. The programs also shifted from only offering part-time education to offering both part-time and full-time education (MOE 2009). Therefore, MEd. programs developed at a rapid pace. Before 2007, there were $49 \mathrm{HEIs}$ offering MEd. programs, and the number increased to 142 by the end of 2016. The enrollment number of part-time MEd. programs, that was less than 200 students in 1997, increased to 11,000 per year in 2005-2009 and was at 8000-10,000 per year in 2010-2014. The enrollment numbers for full-time programs were 3896 students in 2009, 8092 in 2012, and 14,537 in 2016 (Secretariat of National Council of Professional Degrees for Education 2016).

Full-time MEd. programs in China were initiated within the background of the state's strategic plan with a purpose of developing professional degree education as well as enhancing degree levels of teacher education. However, there are following issues undermining the quality of the MEd. programs: (1) time conflicts of inservice teachers as part-time students and (2) the shortage of teacher educators in HEIs, especially in the field of subject teaching (Zhou 2015).

\subsubsection{Improving the System: Reforming the Teacher Certification System}

The teacher certification system, as an occupational access system of the teaching profession, is a systemic guarantee of the open teacher preparation system. China's teacher certification system was gradually established after the Law of Teachers was 
promulgated in 1993, stipulating the state implements teacher certification system. The State Council issued The Regulations of Teacher Certification in 1995, and then the Ministry of Education promulgated the Measures for Implementation of Regulations of Teacher Certification in 2000. In 2001, the teacher certification system entered the full implementation stage. However, with its actual implementation, there emerged problems such as a low threshold requirement for education background, a nonstandard examination system, and a lifelong valid teacher qualification.

The Program Guidelines issued in 2010 proposed building a system including national standards, provincial examinations, and county recruitment for the entry and management of teacher certificates (The State Council 2010), as well as a regular teacher certificate registration system. Later, the MOE started a pilot reform of teacher certification examinations and regular registration in 2011 in Zhejiang and Hubei provinces and extended to 15 provinces in 2014 (MOE 2014a, b, c). In the pilot program, there were three changes, i.e., (1) any candidate regardless of their previous educational background should sit for teacher certification written examination; (2) graduates from the teacher education institutions are not exempted from such examination; and (3) regular certificate registration system is mandated to all every 5 years, including the current in-service teachers.

The effect of the pilot reform of teacher certification system showed that by tightening entry standards to the teaching profession, and introducing teacher certificate registration, the pool of quality teachers was enlarged, and the existing teachers were revitalized (Liu and Zhang 2014; Liu and Zhu 2015; Chen 2018).

However, some challenges emerged along the reform. For example, the validity of the examination was questioned if it alone was sufficient to judge candidates' professional competencies as teachers, and whether this practice was in line with the spirit of teaching professionalization (Liu and Zhang 2014; Liu and Zhu 2015; Chen 2018). In addition, other concerns emerged about whether the requirement of teacher certificate registration every 5-year was appropriate and whether it caused interference in the daily teaching and professional development of teachers (Liu and Zhang 2014; Liu and Zhu 2015; Chen 2018).

\subsubsection{Alleviating Poverty Through Education: Strengthening the Construction of the Rural Teaching Force}

Building a rural teaching force has long been an extremely difficult task and is the weak point in the construction of the teaching force. Teacher education is regarded as an important approach to promote educational equity. Therefore, three policy measures were adopted to strengthen the construction of the rural teaching force and their teacher education. 


\section{Creation and Implementation of the Free Teacher Education Policy}

In 2007, with a purpose of encouraging and attracting excellent college graduates to become lifelong educators in especially underdeveloped areas like the Midwest or rural areas, the Central government created and financially supported free teacher education (FTE) programs in the six national normal universities. According to statistics, 52,000 FTE students graduated from six national normal universities in 2012-2016, and $96.5 \%$ of the graduates went to work in schools abiding by the contracts and $90.3 \%$ went to the Midwest (Huang 2017). Later, in response to the emerging problems during the FTE policy implementation, the MOE adjusted the coverage and responsible institutions, including more local normal universities to carry out the training. By 2017, FTE policy was implemented at local normal universities in 28 provinces, producing about 41,000 FTE graduates every year to teach in rural schools (Huang 2017).

\section{Implementation of Designated MEd. Scheme for Rural Teachers}

The MOE launched the Rural MEd. Scheme in 2004, selecting some excellent graduates each year from several HEIs as candidates of the Rural MEd. Scheme. Those candidates were required to have 3-year teaching experiences in underdeveloped areas and rural schools. The study mode of the program was part-time online learning for the first 3 years and then in the 4th year full-time on-campus learning in the universities where the candidates were graduated. By 2014, the Rural MEd. Scheme attracted a total of 8881 undergraduates to teach in rural schools in underdeveloped areas, which to some extent eased the shortage of teacher leaders known as "backbone teachers" in rural schools. However, it also met with problems in student recruitment, arranging employment, raising funds, quality assurance, and higher turnover rates after graduation (Zhou et al. 2008; Yang 2011).

Implementation of "National Training Programs" for Teachers and Principals. The "National Training Programs for teachers and principals" launched by the Central government in 2010 and 2014 aimed to enhance the overall quality of school teachers, especially those in rural areas. By 2013, the government invested 4.25 billion Yuan to train 4.93 million in-service teachers, of whom 4.73 million were rural school teachers (MOE 2014c). In 2014, the government invested 2.15 billion Yuan to training all rural school teachers of compulsory education in the Midwest (MOE 2014c). The primary objective of the National Training Programs for principals is to train a group of leaders who carried out quality-oriented education and promote the reform and development of basic education in rural areas, especially in the remote and underdeveloped areas. The implementation of the National Training Programs improved the professionality of school teachers, especially those in rural areas in the Midwest (Li and Yang 2018; Wang 2017). However, there still existed the problems associated with the effectiveness of the 
training, such as an unreasonable arrangement of the training time, lack of relevance of training content, and relatively simplified training modes (Wang 2017, 2018).

\subsection{Revitalization}

The year of 2017 marked a new stage to revitalize teacher education in China, because the MOE mentioned this on various important occasions and began to plan and design policy measures addressing this goal.

On August 25, 2017, the MOE convened a "National Working Conference on Revitalizing Teacher Education and Constructing the Teaching Force" in Changchun and highlighted the issue of revitalizing teacher education. On September 6, 2017, Huang Wei, Deputy Director of the Department of Teachers' Affairs, MOE, made a speech entitled "Revitalizing Teacher Education for Education Modernization" at the "Forum on Teacher Development of China-Celebrating the 33rd Teacher's Day" that was held by the Central Committee of China Association for Promoting Democracy. This event stressed once again the necessity of creating a new situation for teacher education revitalization.

In addition, the reports or speeches by the leading officials from the MOE on these two occasions demonstrated that to strengthen and promote quality teacher education, the MOE, at present and for some time to come, will act in accordance with the Chinese Communist Party Central Committee's overall plan for comprehensively promoting the reform and construction of the teaching force in the new era through The Action Plan for Teacher Education Revitalization. The MOE will also act on the following objectives for quality enhancement of teacher education: (1) to highlight teacher professional ethics educations, (2) to address equity through preservice and in-service teacher education, (3) to vigorously promote supply-side structural reform of teacher education, and (4) to build a high-level teacher education system (MOE 2017a; Huang 2017).

As an important measure to construct a high-level teacher education system, the MOE issued Measures for the Implementation of Teacher Education Program Accreditation in General Higher Education Institutions (Interim) (hereinafter referred to as Accreditation Measures) in October, 2017 (MOE 2017b). The Accreditation Measures, which are based on the basic ideas of "student-centeredness, output-orientation and continuous improvement," creates a three-level monitoring and accreditation system for teacher education programs. In accordance with its work arrangement, the MOE decided to start the accreditation of teacher education programs from 2018.

According to The Key Points for the Work of the Department of Teachers Affairs in 2018 (DTAMOE 2018), the Opinions on Deepening the Reform of the Teaching Force Construction in the New Era in an All-Round Way (hereinafter referred to as Opinions on the Teaching Force) (CPCCC and SC 2018) will be promulgated in 
2018 to deepen the reform of the existing teaching force, and the Action Plan for Teacher Education Revitalization is to be promulgated and carried out to promote teacher education revitalization. These two documents will provide an overall vision and blueprint for the teacher education revitalization in China at present and for the time to come.

On January 20, 2018, the CPC Central Committee and the State Council jointly issued Opinions on the Teaching Force. Based on the understanding of the extreme significance of work concerned with teachers' affairs, the Opinions on the Teaching Force focuses on the objectives and tasks for the next 5 years and envisions longterm development through 2035. It also provides overall arrangements for deepening the reform of the existing teaching force through comprehensively strengthening the construction of teachers' ethics and virtue, enhancing the status of teacher education, deepening the comprehensive reform of teacher management, continually improving the status and treatment of teachers, and strengthening the Party's leadership over work related to teacher affairs.

The Opinions on the Teaching Force attaches great importance to the improvement of the teachers' status and treatment, noting that to achieve educational development it is essential to enhance teacher quality and steadily improve teachers' status and treatment simultaneously. To improve teachers' political, social, and professional status, the Opinions on the Teaching Force presents specific measures such as "[improvement of] the long-term linkage mechanism of school teachers' salaries" and proposes that "the actual income levels of local civil servants will be taken into the overall consideration when approving the total amount of school teacher's performance salary".

In addition to these measures to improve the status of school teachers, Opinions on the Teaching Force also presents other objectives such as "to support normal colleges and universities more, and to encourage well-established, qualified high-level comprehensive universities with willingness to provide teacher education programs" and "to upgrade teacher education to a higher level and promote supply-side structural reform of teacher preparation so as to improve the supply of quality teachers resources"(CPCCC and SC 2018). These requirements demonstrate the objective of making teacher education stronger by vigorously supporting teacher education and improving its status.

The Action Plan for Teacher Education Revitalization (2018-2022) has been promulgated in March, 2018. The purpose of this plan is mainly to carry out the basic objectives of Opinions on the Teaching Force: to design concrete measures to vigorously support teacher education, to improve the status of teacher education, and to enhance the quality of teacher education (MOE 2018).

The teacher education policies introduced since 2017 demonstrate that the Chinese government has shown not only a conscientious awareness of revitalizing teacher education but has also grasped the key to the teacher education revitalization; this shows us the dawn of future teacher education revitalization in China. Nevertheless, only time will demonstrate whether teacher education can be revitalized because this reform is still at the early stage, and what we witness now is still only the intention of policies rather than their implementation. 


\section{References}

Chen, L. (2018). Value orientation, implementation status and problems in teacher qualification and national unified examination system. Contemporary Teacher Education, 11(2), 52-57. (In Chinese).

CPCCC \& SC (the Communist Party of China Central Committee and the State Council). (1999). Decisions on deepening educational reform and promoting quality-oriented education in an all-round way. Retrieved October 1, 2010, from http://www.edu.cn/zong_he_870/20100719/ t20100719_497966.shtml. (In Chinese).

CPCCC \& SC. (2018). Opinions on deepening the reform of the teaching force construction in the new era in an all-round way. Retrieved January 31, 2018, from http://www.gov.cn/xinwen/2018-01/31/content_5262659.htm. (In Chinese).

DTEMOE (Department of Teacher Education of the Ministry of Education). (Ed.). (2005). Strengthening and reforming teacher education to serve primary and secondary educationA selected collection of documents and experience materials on teacher education. Beijing: Higher Education Press. (In Chinese).

DTEMOE. (2006). The teaching force: Eight aspects of development. Guangming Daily, September 6. (In Chinese).

DTEMOE (Ed.). (2009). A collection of documents on teacher education and teachers (20012007). Changchun, China: Northeast Normal University Press. (In Chinese).

DTAMOE (Department of Teachers' Affairs of the Ministry of Education). (2018). The key points for the work of the Department of Teachers' Affairs in 2018. Retrieved January 25, 2018, from http://www.MOE.edu.cn/s78/A10/A10_gggs/A10_sjhj/201801/t20180124_325390.html. (In Chinese).

Guan, P. (2004). Ten conceptions of teacher education reform and development. China Higher Education, 2, 24-26. (In Chinese).

Huang, W. (2017). Revitalizing teacher education for education modernization. Teacher's Journal, 20, 16-19. (In Chinese).

Li, J., \& Yang, F. (2018). Teacher training: Forty years of practice and its development trend. Teacher Development Research, 2(4), 17-26. (In Chinese).

Liu, X., \& Zhang, M. (2014). Problem and egress of the reform for the 'national examination' in teacher certification system. Teacher Education Forum, 27(9), 5-10. (In Chinese).

Liu, C., \& Zhu, X. (2015). The research of the national teacher certification examination: Current situation, problem and suggestion. Curriculum, Teaching Material and Method, 35(9), 97-102. (In Chinese).

MOE. (2001). The $10^{\text {th }}$ five-year plan for construction of the teaching force of primary and secondary schools. Retrieved September 12, 2016, from http://www.edu.cn/oldnews_653/20060323/ t20060323_153222.shtml. (In Chinese).

MOE (Ministry of Education). (2001). Outline for basic education curriculum reform. Retrieved October 25, 2016, from http://old.MOE.gov.cn/publicfiles/business/htmlfiles/MOE/ MOE_309/200412/4672.html. (In Chinese).

MOE. (2009). Opinions on how to carry out the work of cultivating full-time professional degree graduate students. .Retrieved December 10, 2016, from http://old.MOE.gov.cn//publicfiles/ business/htmlfiles/MOE/s3493/201002/xxgk_82629.html. (In Chinese).

MOE. (2010). Hot Spots: The construction of primary and secondary school teaching force has reached a new height. .Retrieved January 20, 2010, from http://www.MOE.edu.cn/jyb_sjzl/ MOE_364/MOE_2489/MOE_2513/tnull_40890.html. (In Chinese).

MOE. (2011). Teacher education curriculum standard. Retrieved October 10, 2016, from. http:// old.MOE.gov.cn//publicfiles/business/htmlfiles/MOE/s3702/201110/xxgk_125722.html. (In Chinese).

MOE. (2014a). Accreditation standards for teacher education programs (trial). Retrieved October 10, 2016, from http://edu.imnu.edu.cn/n537c19.jsp. (In Chinese). 
MOE. (2014b). Opinions on implementing excellent teacher preparation programs. Retrieved November 8, 2016, from http://old.MOE.gov.cn//publicfiles/business/htmlfiles/MOE/ s7011/201408/174307.html. (In Chinese).

MOE. (2014c). Branches full of Golden Autumn fruits-30-year fruits of the teaching force construction since the setting-up of Teacher's Day. Retrieved December 21, 2016, from http://old. MOE.gov.cn//publicfiles/business/htmlfiles/MOE/s8285/201409/174427.html. (In Chinese).

MOE. (2016). Opinions on strengthening teaching practice of teacher students. Retrieved October 10, 2016, from http://www.MOE.edu.cn/srcsite/A10/s7011/201604/t20160407_237042.html. (In Chinese).

MOE. (2017a). Revitalize teacher education to strengthen the construction of the teaching force from the source: "National Working Conference on Revitalizing Teacher Education and Constructing the Teaching force" was held. Retrieved December 23, 2017, from http://www. MOE.edu.cn/jyb_xwfb/gzdt_gzdt/MOE_1485/201708/t20170825_311978.html. (In Chinese).

MOE. (2017b). Measures for the implementation of teacher education program accreditation in general higher education institutions (interim). Retrieved November 25, 2017, from http:// www.MOE.edu.cn/srcsite/A10/s7011/201711/t20171106_318535.html. (In Chinese).

MOE. (2018). The Action Plan for Teacher Education Revitalization. Retrieved March 28, 2018, from http://www.gov.cn/xinwen/2018-03/28/content_5278034.htm. (In Chinese).

Nasukawa, T., \& Watanabe, T. (2014). The elevation of the level of preservice and in-service teacher education. Tokyo: The Earth Kyoikushinsha. (In Japanese).

Rao, C. (2007). The Trends and Problems of Teacher Education Reform in China. In Annual Research Report of Curriculum Center for Teachers at Tokyo Gakugei University (Vol. 6, pp. 39-50). Tokyo: Tokyo Gakugei University. (In Japanese).

Rao, C. (2013). The reform and development of teacher education in China and Japan in an era of social change. In E. Kimonen \& R. Nevalainen (Eds.), Transforming teachers'work globally: In search of a better way for schools and their communities. Rotterdam: Sense Publishers.

Ren, Y., et al. (1998). An Exploration on teaching practice in normal universities and colleges. Journal of Hebei Normal University (Educational Science), 1(2), 93-96. (In Chinese).

Sato, M. (2015). Educating teachers to be professionals. Tokyo: Iwanami Shoten. (In Japanese).

Secretariat of National Council of Professional Degrees for Education. (2016). Basic Situations of professional degrees in education. Retrieved December 15, 2017, from http://edm.eduwest. com//viewnews.jsp?id=41 (In Chinese).

The State Council. (2001). Decisions on reform and development of basic education. Retrieved October 15, 2015, from http://old.MOE.gov.cn/publicfiles/business/htmlfiles/MOE/ MOE_16/200105/132.html. (In Chinese).

The State Council. (2010). Guidelines of the national program for medium and long-term educational reform and development (2010-2020). .Retrieved December 10, 2012, from http:// old.MOE.gov.cn/publicfiles/business/htmlfiles/MOE/info_list/201407/xxgk_171904.html. (In Chinese).

The State Council. (2012). Opinions on strengthening the construction of the teaching force. Retrieved October 25, 2016, from http://old.MOE.gov.cn//publicfiles/business/htmlfiles/MOE/ MOE_1778/201209/141772.html. (In Chinese).

Wang, D. (2017). Working hard to push teacher training to a new level. The In-service Teacher Education and Training of School Teachers, 6, 1-6. (In Chinese).

Wang, H. (2018). Five dilemmas binding teacher training. Guangming Daily, (April 12). (In Chinese).

Xu, J. (2008). Post-baccalaureate teacher education in developed countries and its implications to China. Journal of Zhejiang Normal University, 33(3), 75-78. (In Chinese).

Yang, W. (2011). Problems and solutions for the development of the master of rural education. Journal of Educational Science of Hunan Normal University, 5, 60-63. (In Chinese).

Yu, X. (2010). A study of the teacher education policies in China in the era of great transformation (PhD dissertation). Northeast Normal University. (In Chinese). 
Zhang, G., \& Rao, C. (2002). Some understanding and thinking on integration of teacher education. Curriculum, Teaching Material and Method, 5, 58-62. (In Chinese).

Zhao, L. (2000). The developmental orientation of our country's higher normal education at the turn of the century. Journal of Fujian Teachers University (Philosophy and Social Sciences Edition), 1, 140-144. (In Chinese).

Zhong, B. (2010). Promote the flexible and diversified preparation to improve the quality of teacher education. China Higher Education, 19, 13-16. (In Chinese).

Zhou, H. (1997). On the synergistic benefit of teaching practice. Teacher Education Research, 3, 28-32. (In Chinese).

Zhou, X. (2015). The development, problems and countermeasures of Ed. M Programs—based on the investigation and analysis of 24 universities. Academic Degrees and Graduate Education, 2, 36-40. (In Chinese).

Zhou, Q., et al. (2008). Analysis of policy of ED. M programs for rural education. Education and Vocation, 15, 13-15. (In Chinese).

Congman Rao, Director and professor of the Institute of International and Comparative Education, Northeast Normal University at Changchun, P. R. China. He specializes in issues related to comparative education, teacher education, and citizenship and moral education. E-mail: raocm506@nenu.edu.cn.

Open Access This chapter is licensed under the terms of the Creative Commons Attribution 4.0 International License (http://creativecommons.org/licenses/by/4.0/), which permits use, sharing, adaptation, distribution and reproduction in any medium or format, as long as you give appropriate credit to the original author(s) and the source, provide a link to the Creative Commons licence and indicate if changes were made.

The images or other third party material in this chapter are included in the chapter's Creative Commons licence, unless indicated otherwise in a credit line to the material. If material is not included in the chapter's Creative Commons licence and your intended use is not permitted by statutory regulation or exceeds the permitted use, you will need to obtain permission directly from the copyright holder. 